\title{
Morphological variation and sex-biased frequency of wing dimorphism in the pygmy grasshopper Tetrix subulata (Orthoptera: Tetrigidae)
}

\author{
ANJA STEENMAN ${ }^{1}$, ARNe W. LEHMANN ${ }^{2}$ and GERLIND U.C. LEHMANN ${ }^{1 *}$ \\ ${ }^{1}$ Humboldt-Universität zu Berlin, Department of Biology, Behavioural Physiology, Invalidenstrasse 43, 10115 Berlin, Germany, \\ e-mails: anjasteenman@yahoo.de; gerlind.lehmann@t-online.de \\ ${ }^{2}$ Friedensallee 37, 14532 Stahnsdorf, Germany, e-mail: arne.w.lehmann@t-online.de
}

Key words. Orthoptera, Caelifera, Tetrigidae, Tetrix subulata, pygmy grasshopper, polymorphism, polyphenism, wing-dimorphism, sex-biased frequency

\begin{abstract}
Dimorphism in wing length is well known in many insect species. It is generally believed that a trade-off between dispersal and reproduction exists, with the long-winged (LW) morph being a better disperser due to its superior flight capability. The short-winged (SW) morph is less mobile and it is hypothesised that females of this morph invest more of their energy reserves in producing offspring. We determined the variation in body and wing size in the pygmy grasshopper Tetrix subulata (Orthoptera: Tetrigidae). The results of the morphological study support the occurrence of two clearly distinct wing morphs in both sexes. SW individuals, especially males, were smaller and in accord with proposed developmental instability showed greater variability in body size than LW individuals. Using data for 700 wild-caught individuals from 10 populations, we demonstrate a variable frequency in the percentage of LW individuals, ranging from all-LW to all-SW populations, even if the LW morph is by far the most common morph in an area. The male-biased percentage of LW individuals recorded in intermediate populations supports a difference in the dispersal reproduction trade-off between the sexes.
\end{abstract}

\section{INTRODUCTION}

Where flight is the main dispersal mode, variation in dispersal ability and its morphological equivalent (wing polymorphism) is widespread and found in numerous insect species (Harrison, 1980; Roff, 1986; Zera \& Denno, 1997; Zera, 2009; Simpson et al., 2011) and has ecological and evolutionary consequences (Roff, 1994; Schwander \& Leimar, 2011). While flight can be used to colonize new habitats (Denno et al., 1996; Langellotto et al., 2000; Langellotto \& Denno, 2001) energy is required to develop and maintain the flight-apparatus. Energy costs might be limited by physiological constraints (Harshman \& Zera, 2007; Zera, 2009). Flying individuals have higher metabolic rates even at rest (Reinhold, 1999; Chown et al., 2007) and store considerable amounts of energy for fuelling flight (Zera, 2005, 2009; Zera \& Zhao, 2006).

Interestingly, the majority of Orthoptera (grasshoppers, crickets and bushcrickets) in Central Europe are wingdimorphic or polymorphic (Harz, 1969, 1975; Ingrisch \& Köhler, 1998). It is suggested that the high level of wing polymorphism is a result of repeated cycles of extensive glaciation in Central Europe during the last 2 million years (Hewitt, 2004; Schmitt, 2007). Recolonization from Asian and Mediterranean refuges may have favoured species with high colonization capacities, as proposed for wing-dimorphic carabid beetles (Aukema, 1995).

In the pygmy grasshoppers (Tetrigidae), which are small, ground dwelling orthopterans that form an ancient clade within the short-horned suborder Caelifera (Flook \& Rowell, 1997), there is a similar pattern. In this group, the forewings are reduced to a 1-3 mm long tegmentulum (Devriese, 1996), while the pronotum is prolonged and covers the abdomen and hind wings. The West Palaearctic species vary in their mixture of hindwingpolymorphism, with most species being predominantly LW or SW (Devriese, 1996; Lehmann \& Landeck, 2007).

We studied populations of Tetrix subulata (Linnaeus, 1758), because in this species two wing morphs occur within the same population (Devriese, 1996; Lock et al., 2006; Berggren et al., 2012). In the SW morph the pronotum reaches the knees of the hind femurs and the folded hind wings the tip of the pronotum. Individuals described as long-winged, develop hind wings and pronota that overhang the knees by several millimetres. However, previous studies have classified individuals visually and only provide measurements of the extended pronotum (Lock et al., 2006; Berggren et al., 2012). In order test for the existence of distinct wing morphs we measured wing size in this study.

Observations indicate that the occurrence of the SW morph in $T$. subulata is associated with poor habitats, such as those at high altitudes (Fontana et al., 2002; Meitzner, unpubl. data) or high latitudes (Rehn \& Grant, 1955; Helfer, 1987). Such marginal habitats restrict life cycles, which poses the question is the expression of SW a developmental reaction of less fit individuals (King \& Roff, 2010). If this is the case then the expectation is that SW individuals will be smaller than LW individuals.

\footnotetext{
* Corresponding author.
} 
Interestingly, most wing-dimorphic Orthoptera are predominantly short winged. LW individuals tend to occur more frequently when population densities are high. However over much of the range of Tetrix subulata the LW morph is more common than the SW morph (Harz, 1975; Helfer, 1987). If development is modified by environmental or physiological stress we expect a great degree of phenotypic variation in morphological traits (West-Eberhard, 2003; Badyaev, 2005, 2011). Therefore, it can be hypothesized that a greater variation in wing length and body size will occur among SW than LW individuals.

Finally, using field observations we document the pattern in spatio-temporal variation in wing morph frequencies in relation to habitat quality and population size. Special emphasis is given to sex-biased differences in morph frequencies. Since females invest much more energy in reproduction than males it is likely that females in poor habitats or conditions will switch their development from LW to SW individuals before males are affected. In habitats of intermediate quality it is likely that LW males will occur more frequently than LW females.

\section{MATERIAL AND METHODS}

\section{Model species}

The Slender grasshopper Tetrix subulata (Linnaeus, 1758) belongs to the primitive family Tetrigidae (Orthoptera: Caelifera). It is widespread throughout the temperate regions of Europe (Harz, 1975; Devriese, 1996), Asia (Podgornaya, 1983; Storozhenko, 2009) and North America (Rehn \& Grant, 1955; Helfer, 1987). T. subulata is the commonest Tetrigidae species in Germany (Maas et al., 2002) and in the study area in Brandenburg (Höhnen et al., 2000). T. subulata lives in wetlands, especially in areas of desiccated mud close to water (Hochkirch et al., 1999), where it feeds on mosses, algae and detritus (Hochkirch et al., 2000). Adults hibernate and mate and lay eggs in spring and early summer (Ingrisch \& Köhler, 1998). First nymphs can be found at the beginning of June and they become adult at the end of August (Ingrisch \& Köhler, 1998; our data confirm they follow a similar life cycle in the study area in Brandenburg).
We collected individuals of $T$. subulata from a large population situated $20 \mathrm{~km}$ south west of Berlin. They inhabited sandy areas between low grass and mosses in a marsh on the east shore of lake "Großer Zernsee" north of Werder / Havel $\left(52^{\circ} 24^{\prime} 13.363^{\prime \prime} \mathrm{N}, 12^{\circ} 56^{\prime} 5.873^{\prime \prime} \mathrm{E}\right)$. Adult individuals were collected between early May and mid-June 2010. They were placed in small jars and transferred to the laboratory. In order to avoid the female-bias associated with hand collecting the specimens were collected using a sweep net (Berggren et al., 2012; unpubl. data).

\section{Body dimensions}

We used the length of the hind femur as a wing-independent body size parameter. Wing length dimorphism in Tetrigidae is restricted to the hind wings (= alae), whereas the minute front wings (= tegmentula) do not differ in length. Wing dimorphism was, therefore, assessed by measuring the hind wings of individuals with their wings folded under the elongated pronotum. All measurements of wings and femurs were done under a binocular microscope (Wild M3C, Heerbrugg, Switzerland, accuracy of graticule measurements $\pm 0.01 \mathrm{~mm}$ ).

\section{Spatio-temporal variation in the frequencies of the different wing-morphs}

In order to determine the spatio-temporal variation in the frequencies of different wing-morphs in different populations more than 700 individuals were collected from ten randomly chosen populations between 2003 and 2011 in Brandenburg, Germany (Table 1). Using the data on the distribution of different wingsizes we classified all individuals as either LW or SW. To test for temporal variation in wing-morph frequencies both the spring and the autumn cohorts from two populations (Belziger Landschaftswiesen and Großer Zernsee) were sampled.

\section{RESULTS}

\section{Variation in wing-length supports dimorphism}

Wing length in T. subulata varied significantly between sexes, with females having longer hindwings than males (two way ANOVA factor sex: $\mathrm{F}_{1,318}=609.34, P<0.01$ ). In both sexes hindwing length showed a bimodal distribution (Fig. 1a, b), which indicates there are two different wing morphs and permits the identification of all animals as either short winged (SW) or long winged (LW).

TABLE 1. Frequency of short winged and long winged individuals, of both males and females, recorded in the different populations sampled in Brandenburg, Germany.

\begin{tabular}{|c|c|c|c|c|c|c|c|}
\hline \multirow{2}{*}{ Locality } & \multirow{2}{*}{ Date } & \multicolumn{3}{|c|}{ Males } & \multicolumn{3}{|c|}{ Females } \\
\hline & & LW (n) & SW (n) & LW [\%] & LW (n) & SW (n) & LW [\%] \\
\hline Schlepzig & 01.vi.2008 & 70 & & 100 & 70 & & 100 \\
\hline Odertal Criewen & 10.iv.2009 & 17 & & 100 & 14 & & 100 \\
\hline Belziger & 22.v.2011 & 10 & & 100 & 11 & & 100 \\
\hline Landschaftswiesen & 04.ix.2011 & 23 & & 100 & 17 & & 100 \\
\hline Meßdunk & 09.v.2011 & 9 & 1 & 90 & 10 & 3 & 77 \\
\hline \multirow{3}{*}{ Potsdam Nattwerder } & 09.-15.v.2009 & 51 & 10 & 84 & 34 & 5 & 87 \\
\hline & 08.-19.vi.2009 & 55 & 12 & 82 & 37 & 7 & 84 \\
\hline & 02.ix.2009 & 9 & 2 & 82 & 9 & 0 & 100 \\
\hline Brandenburg & 06.iv.2009 & 59 & 25 & 70 & 18 & 14 & 56 \\
\hline Pritzerber See Fohrde & 05.iv.2011 & 14 & 10 & 58 & 6 & 10 & 38 \\
\hline Luckau $10 \mathrm{~km} \mathrm{~N}$ & 20.iv. 2003 & 5 & 6 & 45 & 2 & 9 & 18 \\
\hline Kirchmöser & 19.iv.2011 & 5 & 21 & 19 & 4 & 20 & 17 \\
\hline Brandenburg & 16.iv.2011 & & 4 & 0 & & 7 & 0 \\
\hline
\end{tabular}



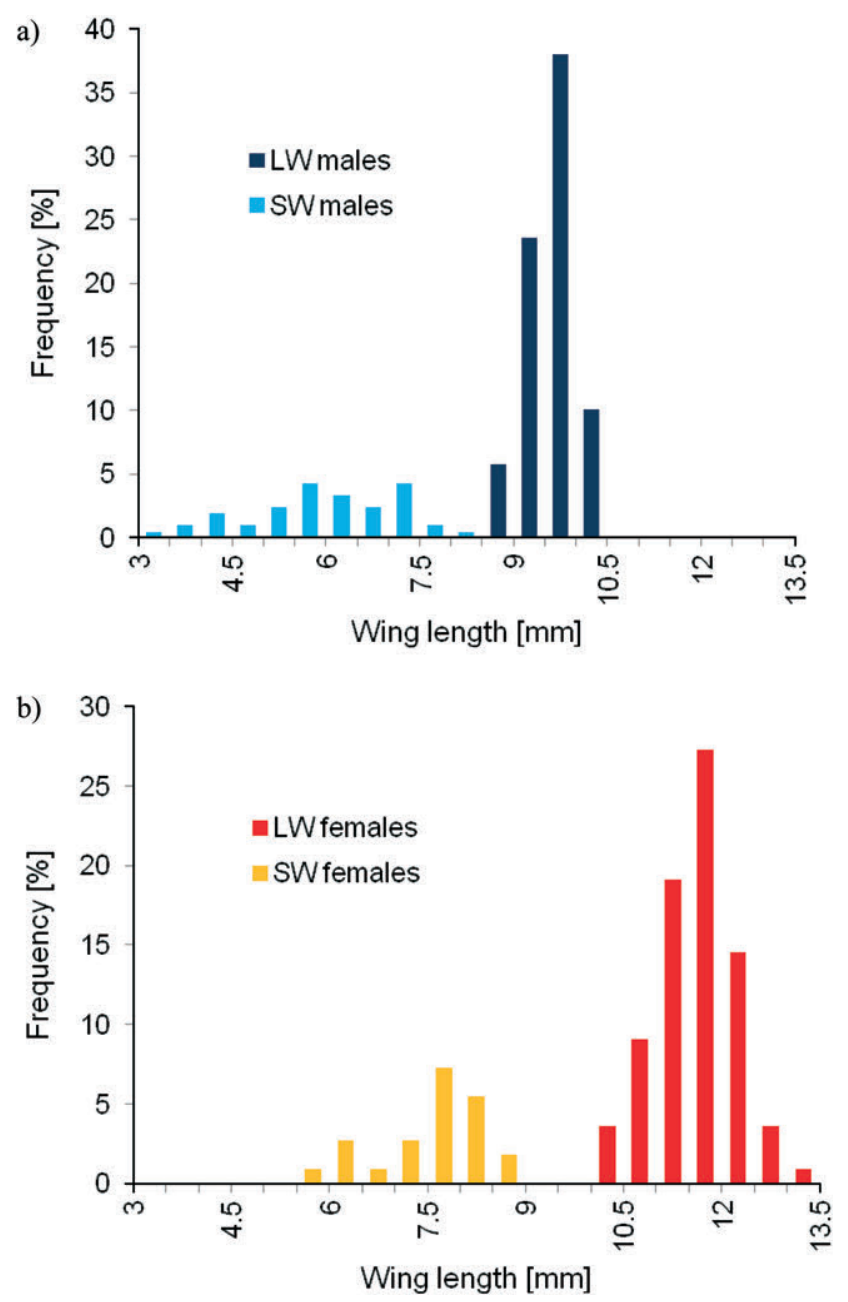

Fig. 1. Frequency distribution of the wing lengths of a) males (light blue and dark blue) and b) females (orange and red) of Tetrix subulata.

Specimens assigned to the LW or SW morph differed greatly in wing length (two way ANOVA factor wing morph: $\left.\mathrm{F}_{1,318^{\prime}}=1631.70, P<0.001\right)$. The extent of wing dimorphism differed between the sexes. The mean wing length of LW females exceeded that of SW individuals by only $49 \%$ (Posthoc test Bonferroni critical mean differences between group pairs: $q_{\text {wing length }} \mathrm{LW}>\mathrm{SW} ; P<$ $0.001)$, whereas this difference was significantly greater in males (two way ANOVA interaction wing morph $\mathrm{x}$ sex: $\mathrm{F}_{1,318}=2.78, P<0.014$ ), with the wings of $\mathrm{LW}$ individuals $60 \%$ longer than those of SW males ( $\hat{O}_{\text {wing length }}$ LW $>$ SW; $P<0.001$ ). Errors in development probably occurred in the SW morph, as the variation in wing lengths was greater in SW than LW individuals (Bartletttest rejecting equal variances: $\left.\chi^{2}{ }_{1}=134.18, P<0.001\right)$. This variation was even more pronounced in males (coefficient of variation: $\mathrm{SW}=18.94>\mathrm{LW}=3.77$ ) than females $(\mathrm{CV}: \mathrm{SW}=13.82>\mathrm{LW}=5.70)$.

\section{Differences in body size}

Measurement of hind femur length revealed significant differences in body size between sexes and wing morphs (Fig. 2). Females are the larger sex, with longer hind

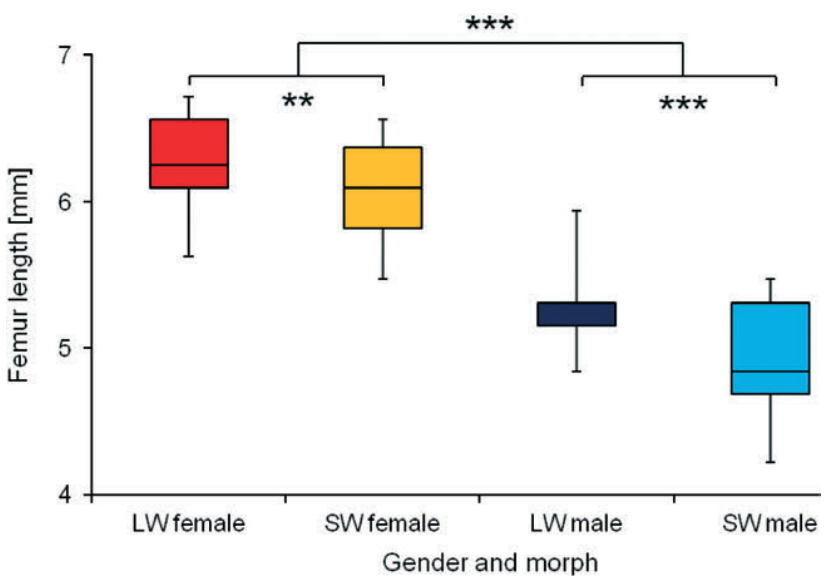

Fig. 2. The lengths of the femurs of both wing morphs of female and male $T$. subulata. (Box plots: Q1, Q3, median, minimum and maximum, $\mathrm{n}=86,24,161,47) . * * P<0.01 ; * * *$ $P<0.001$.

femurs than males (two way ANOVA, effect of sex: $\mathrm{F}_{1,318}$ $=1260.41, P<0.001)$. As predicted by the reproduction compensation hypothesis, LW individuals were larger and had longer hind femurs than their SW conspecifics (two way ANOVA, effect of wing morph: $\mathrm{F}_{1,318}=61.31, P<$ 0.001). This is the case for both females (Posthoc test Bonferroni critical mean differences between group pairs: $\left.{ }_{+}{ }_{\text {hind femur }} \mathrm{LW}>\mathrm{SW} ; P<0.01\right)$ and males ( $\hat{o}_{\text {hind femur }} \mathrm{LW}>$ SW; $P<0.001$ ). Body size based on hind femur length was equally variable for $\mathrm{SW}$ and $\mathrm{LW}$ females (CV: $\mathrm{SW}=$ $5.50=\mathrm{LW}=4.64)$ and only slightly greater for $\mathrm{SW}$ males $(\mathrm{CV}: \mathrm{SW}=7.02>\mathrm{LW}=3.62$ ).

\section{Spatio-temporal variation in wing-morph frequencies}

The frequency of occurrence of individuals with the different wing-lengths differed considerably between the ten Brandenburg populations sampled, ranging from all-LW to all-SW individuals. Populations consisting of only LW individuals were the most common, which was the case for three out of the ten populations sampled. Two populations had more than $80 \% \mathrm{LW}$ individuals. Interestingly, in populations where the two wing morphs were more equally represented the males were predominantly LW (Fig. 3). Repeated sampling in two populations revealed nearly identical percentages of LW-individuals, which indicates there is no seasonal variation in the frequency of the two morphs. The population at Belziger Landschaftswiesen consisted of only LW individuals both in spring and autumn. In the Großer Zernsee population, near Potsdam, 82 to $84 \%$ of the males and 84 to $100 \%$ of the females had long wings in spring and autumn, respectively.

\section{DISCUSSION}

As is typical of the majority of insect species (Fairbairn, 1997; Blanckenhorn et al., 2007; Chown \& Gaston, 2010), including Orthoptera (Hochkirch \& Gröning, 2008; Lehmann \& Lehmann, 2008b; Whitman, 2008), the female is the larger sex in T. subulata. As the bimodal distribution of wing lengths shows $T$. subulata is 


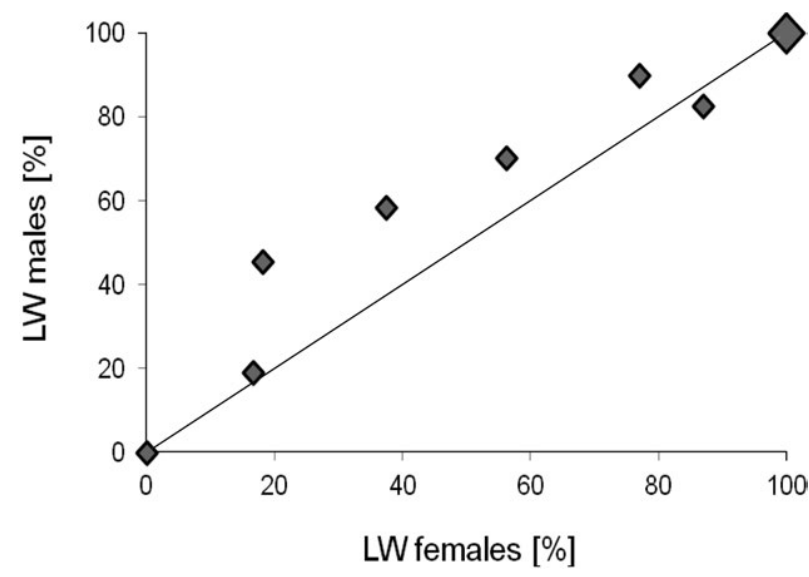

Fig. 3. Plot of the percentages of males and females that are long winged in the different $T$. subulata populations. LW males occurred in higher percentages than LW females, especially in populations with intermediate frequencies of $\mathrm{LW}$ individuals.

clearly wing dimorphic (Fig. 1a, b). The two different wing morphs occurred in both sexes, with the wings of LW individuals around $60 \%$ longer in males and $40 \%$ longer in females than in SW individuals.

The development of a particular wing morph might be condition dependent and reflect adaptive plasticity in relation to environmental factors such as maternal condition, population density or food intake (Harrison, 1980; Zera \& Denno, 1997; Simmons \& Thomas, 2004; Roff \& Fairbairn, 2007; Pener \& Simpson, 2009; Poniatowski \& Fartmann, 2009) as well as temperature and photoperiod (Spence \& Andersen 1994; but see Ditrich \& Papáček 2009). That wing morph is dependent on environmental conditions is possibly supported by the development of long winged individuals when conditions for growth were good and that the hind femur length of SW individuals was clearly shorter than that of LW individuals of both sexes (Fig. 2). The SW morph predominates in marginal habitats at high altitudes (Fontana et al., 2002; Meitzner, unpubl. data) and high latitudes (Helfer, 1987). The LW individuals probably require more energy, as Lock et al. (2006) record that LW individuals of T. subulata consume more food (energy) and contain more protein than SW individuals. However, the greater mobility of LW individuals might allow them to find better sources of food, as free ranging individuals of the different morphs differ in their stable isotope signatures (Karpestam \& Forsman, 2013). Phenotypic variation in Swedish $T$. subulata has a clear genetic background, as there is a strong association between wing length of the parental generation collected from the field and the wing-morph frequencies of their captive-reared offspring (Berggren et al., 2012). However, a maternal affect on wing morph frequencies cannot be ruled out, as only the first generation of offspring was studied (Berggren et al., 2012).

The developmental pathway leading to the distinct wing morphs in T. subulata might become unbalanced by a switch from one program to another (West-Eberhard, 2003; Badyaev, 2005, 2011). Since the LW morph is the original morph in T. subulata (Harz, 1975) it is likely that the derived SW morph will show a greater phenotypic variation in morphological traits. This prediction was supported by the results of the study of wing length in $T$. subulata, in which the variation in the SW morph was much greater than in the LW morph (Fig. 1a, b). However, no developmental stress could be inferred from body size because the variation in hind femur length was only moderately greater in the SW morph (Fig. 2). This supports the occurrence of both sex and trait specific variation, and therefore it might be worth exploring the basis of such variation, especially under controlled breeding conditions.

In nearly all other wing dimorphic Orthoptera the pattern is reversed, with the $\mathrm{SW}$ morph the most common morph and the LW morph induced by environmental factors such as high population density (Ingrisch \& Köhler, 1998; Pener \& Simpson, 2009; Poniatowski \& Fartmann, 2009). In support of this idea is that a higher variation in wing length is recorded for the LW morph of the grasshopper Chorthippus parallelus (Berger, 1988). To reduce the cost of developing wings it might be beneficial to switch the default developmental program from LW to SW. By doing so, females might increase their fecundity (Guerra, 2011). In T. subulata SW females allocate more resources to reproduction than LW females, as they produce larger eggs but a similar number of eggs and egg pods (Steenman et al., submitted). Therefore, it is very likely there is a trade-off between reproduction and dispersal (Stearns, 1992; Roff 2002).

In the field $T$. subulata shows considerable spatial variation in frequencies of wing morphs in different populations ranging from all-LW to all-SW individuals. The LW clearly outnumbered the SW morph in our study area, as half of the populations were either exclusively long winged or their percentage was very high (above $80 \%$ ). At the other end of the spectrum there was only one all-SW population. Furthermore, morph frequencies remained stable during the course of a year in two repeatedly sampled populations, with little variation between the individuals in the spring and autumn cohorts. Interestingly, the morph frequencies showed a previously unreported sex-biased difference (Lock et al., 2006; Berggren et al., 2012), with a shift towards more LW males in populations in habitats of medium quality. Females with their assumed greater investment in reproduction might switch their developmental program from LW to SW in habitats deteriorating in quality before the males. Such a sex-biased occurrence of morph frequencies could be a further indicator of condition dependent expression of wing-morphs in $T$. subulata. Berggren et al. (2012) recorded LW individuals more frequently in burned areas and related the dominance of the LW morph to the instability of this habitat. However, an alternative factor favouring LW individuals might be the better body condition of the parents, since nutrients from plant material might be released by fires, and is suggested as the factor inducing wing dimorphism in Japanese carabids (Yamashita et al., 2006). 


\section{CONCLUSIONS}

Environmentally induced polymorphisms that result from a genotype by environment interaction provide excellent systems for studying the mechanisms of development and maintenance of phenotypic plasticity (Roff, 1996; West-Eberhard, 2003; Tomkins \& Hazel, 2007; Schwander \& Leimar, 2011). In this respect T. subulata could be a good model system, because wing dimorphism in this species seems to have both an environmental (Steenman et al., in prep.; this paper) and a genetic (Berggren et al., 2012) component. In addition the two phenotypes can be easily distinguished in the field and there are obvious differences in morph frequencies between habitats (Berggren et al., 2012; this paper). This variation might be associated with habitat quality, with SW individuals more common in marginal habitats. Furthermore, as the long winged morph is capable of dispersal (Berggren et al., 2012), individuals of both sexes can leave poor habitats.

More studies are necessary to differentiate between the genetic and environmental contribution to wing dimorphism in T. subulata. A phylogenetic approach to wing dimorphism might be appropriate in this case (Schwander \& Leimar, 2011). However, results of studies on salamanders indicate that the mechanisms determining the development of different morphs need to be considered, as identical morphs can evolve in different environmental and genetic contexts (Whiteman et al., 2012).

What makes the system studied especially interesting is the sex-bias in morph frequencies in populations in intermediate quality habitats, which seems to reflect differences in the trade-off between dispersal and reproduction in the two sexes.

ACKNOWLEDGEMENTS. Author Contributions: GL formulated the idea; GL, AS developed the methodology, AS did the fieldwork and performed the experiments. The analyses of the data and statistics were done by AS, AL and GL, and the manuscript was written by AL and GL. We thank R. Hickson for reading the manuscript.

\section{REFERENCES}

AuKema B. 1995: The evolutionary significance of wing dimorphism in carabid beetles (Coleoptera: Carabidae). - Res. Pop. Ecol. 37: 105-110.

BADYAEV A.V. 2005: Stress-induced variation in evolution: from behavioural plasticity to genetic assimilation. - Proc. R. Soc. (B) 272: 877-886.

BADYAEV A.V. 2011: Origin of the fittest: link between emergent variation and evolutionary change as a critical question in evolutionary biology. - Proc. R. Soc. (B) 278: 1921-1929.

BERgER M. 1988: Mehrjährige ökologische Untersuchungen an einer Grashüpfer-Population (Orthoptera: Acrididae). $\mathrm{PhD}$ Dissertation Univ Marburg, Marburg, Germany.

Berggren H., Tinnert J. \& Forsman A. 2012: Spatial sorting may explain evolutionary dynamics of wing polymorphism in pygmy grasshoppers. - J. Evol. Biol. 25: 2126-2138.

Blanckenhorn W.U., Dixon A.F.G., Fairbairn D.J., Foellmer M.W., Gibert P., Van Der Linde K., Meier R., Nylin S., Pitnick S., Schoff C., Signorelli M., Teder T. \& Wiklund C. 2007: Proximate causes of Rensch's rule: does sexual size dimorphism in arthropods result from sex differences in development time? - Am. Nat. 167: 245-257.

Chown S.L. \& Gaston K.J. 2010: Body size variation in insects: a macroecological perspective. - Biol. Rev. 85: 139-169.

Chown S.L., Marais E., Terblanche J.S., Klok C.J., Lighton J.R.B. \& BLACKBURN T.M. 2007: Scaling of insect metabolic rate is inconsistent with the nutrient supply network model. - Func. Ecol. 21: 282-290.

Denno R.E., Roderick G.K., Peterson M.A., Huberty A.F., Dobel H.G., Eubanks M.D., Losey J.E. \& Langellotto G.A. 1996: Habitat persistence underlies intraspecific variation in the dispersal strategies of planthoppers. - Ecol. Monogr. 66: 389-408.

DEVRIESE H. 1996: Bijdrage tot de systematiek morfologie en biologie van de West-Palearkitsche Tetrigidae. - Saltabel 15: 2-38.

Ditrich T. \& PAPÁČEK M. 2009: Correlated traits for dispersal pattern: Terrestrial movement of the water cricket Velia caprai (Heteroptera: Gerromorpha: Velidae). - Eur. J. Entomol. 106: 551-555.

FAIRBAIRN D.J. 1997: Allometry for sexual size dimorphism: pattern and process in the coevolution of body size in males and females. - Annu. Rev. Ecol. Syst. 28: 659-687.

Flook P. \& Rowell C.H.F. 1997: The phylogeny of the Caelifera (Insecta, Orthoptera) as deduced from mtRNA gene sequences. - Mol. Phyl. Evol. 8: 89-103.

Fontana P., Buzetti F.M., Cogo A. \& Odé B. 2002: Guida al riconoscimiento e allo studio di Cavallette, Grilli, Mantidi e insetti affini del Veneto. Guide Natura 1. Museo Naturalistico Archaeologico di Vicenza, Italy, 590 pp.

GuERrA P.A. 2011: Evaluating the life-history trade-off between dispersal capability and reproduction in wing dimorphic insects: a meta-analysis. - Biol. Rev. 86: 813-835.

Harrison R.G. 1980: Dispersal polymorphisms in insects. Annu. Rev. Ecol. Syst. 11: 95-118.

Harshman L.G. \& Zera A.J. 2007: The cost of reproduction: the devil in the details. - Trends Ecol. Evol. 22: 80-86.

HartLey J.C. 1962: The egg of Tetrix (Tetrigidae, Orthoptera), with a discussion on the probable significance of the anterior horn. - Quart. J. Microscop. Sci. 103: 253-259.

HARz K. 1969: Die Orthopteren Europas - The Orthoptera of Europe I. Dr. W. Junk, The Hague, 749 pp.

HaRz K. 1975: Die Orthopteren Europas - The Orthoptera of Europe II. Dr. W. Junk, The Hague, 939 pp.

Helfer J.R. 1987: How to know the grasshoppers, crickets, cockroaches and their allies. Dover Publications, New York, $363 \mathrm{pp}$.

HewitT G.M. 2004: The structure of biodiversity - insights from molecular phylogeography. - Front. Zool. 1: 4.

HochKIrCh A. \& GRÖNING J. 2008: Sexual size dimorphism in Orthoptera (sens. str.) - a review. - J. Orthopt. Res. 17: 189-196.

Hochkirch A., Folger M., Länder S., Meyer C., Papen M. \& ZimmermanN M. 1999: Habitatpräferenzen von Tetrix subulata (Linnaeus, 1758) und Tetrix tenuicornis - (Sahlberg, 1893) in einer Sandkuhle bei Bremen (Orthoptera: Tetrigidae). - Articulata 14: 31-43.

Hochkirch A., Gröning J., Loos T., Metzing C. \& Reichelt M. 2000: Specialized diet and feeding habits as key factors for the habitat requirements of the grasshopper species Tetrix subulata (Orthoptera: Tetrigidae). - Entomol. Gener. 25: $39-51$

Höhnen R., Klatt R., Machatzi B. \& Möller S. 2000: Vorläufiger Verbreitungsatlas der Heuschrecken Brandenburgs. — Märk. Entomol. Nachr. 2000/1: 1-71. 
INGRISCH S. \& KÖHLER G. 1998: Die Heuschrecken Mitteleuropas. Westarp, Magdeburg, $460 \mathrm{pp}$.

Karpestam E. \& Forsman A. 2013: Stable isotopes reveal dietary divergence between dispersal phenotypes in Tetrix subulata pygmy grasshoppers (Orthoptera: Tetrigidae). - Eur. J. Entomol. 110: 65-70.

KING E.G. \& Roff D.A. 2010: Modeling the evolution of phenotypic plasticity in resource allocation in wing-dimorphic insects. - Am. Nat. 175: 702-716.

Langellotto G.A. \& Denno R.T. 2001: Benefits of dispersal in patchy environments: mate location by males of a wingdimorphic insect. - Ecology 82: 1870-1878.

Langellotto G.A., Denno R.T. \& Ott J.R. 2000: A trade-off between flight capability and reproduction in males of a wing-dimorphic insect. - Ecology 81: 865-875.

Lehmann A.W. \& Landeck I. 2007: Pigmy grasshoppers (Orthoptera: Tetrigidae) from North-eastern Turkey. Articulata 22: 225-234.

Lehmann G.U.C. \& Lehmann A.W. 2008: Variation in body size among populations of the bushcricket Poecilimon thessalicus (Orthoptera: Phaneropteridae): an ecological adaptation? - J. Orthopt. Res. 17: 165-169.

Lock K., Verslycke T. \& JANSSEN C.R. 2006: Energy allocation in brachypterous versus macropterous morphs of the pygmy grasshopper Tetrix subulata (Orthoptera: Tetrigidae). Entomol. Gener. 28: 269-274.

MaAs S., Detzel P. \& Staudt A. 2002: Gefährdungsanalyse der Heuschrecken Deutschlands. Bundesamt für Naturschutz, Bonn, $401 \mathrm{pp}$.

Pener M.P. \& Simpson S.J. 2009: Locust phase polyphenism: an update. - Adv. Insect Physiol. 36: 1-286.

Podgornaja L.I. 1983: Orthopteran insects of family Tetrigidae (Orthoptera) of the fauna of USSR. Leningrad: Nauka, $96 \mathrm{pp}$. [in Russian].

Poniatowski D. \& Fartmann T. 2009: Experimental evidence for density-determined wing dimorphism in two bush-crickets (Ensifera: Tettigoniidae). — Eur. J. Entomol. 106: 599-605.

ReHN J.A.G. \& GRANT H.J. JR. 1955: Tetrix subulata (Orthoptera; Acridoidea; Tetrigidae) as occurring in North America. - Proc. Acad. Nat. Sci. Philadelphia 107: 145-165.

REINHOLD K. 1999: Energetically costly behaviour and the evolution of resting metabolic rate in insects. - Funct. Ecol. 13: 217-224.

RofF D.A. 1986: The evolution of wing dimorphism in insects. - Evolution 40: 1009-1020.

RoFF D.A. 1994: Habitat persistence and the evolution of wing dimorphism in insects. - Am. Nat. 144: 772-798.

RofF D.A. 1996: The evolution of threshold traits in animals. Quart. Rev. Biol. 71: 3-35.

RofF D.A. 2002: Life History Evolution. Sinauer Associates, Sunderland, $527 \mathrm{pp}$.
RofF D.A. \& Fairbairn D.J. 2007: The evolution of trade-offs: where are we? - J. Evol. Biol. 20: 433-447.

Sснмiтt T 2007: Molecular biogeography of Europe: Pleistocene cycles and postglacial trends. - Front. Zool. 4: 11. doi:10.1186/1742-9994-4-11

Schwander T. \& Leimar O. 2011: Genes as leaders and followers in evolution. - Trends Ecol. Evol. 26: 143-151.

Simmons A.D. \& Thomas C.D. 2004: Changes in dispersal during species' range expansions. - Am. Nat. 164: 378-395.

Simpson S.J., Sword G.A. \& Lo N. 2011: Polyphenism in insects. - Curr. Biol. 21: R738-R749.

SPENCE J.R. \& ANDERSEN N.M. 1994: Biology of water striders -interactions between systematics and ecology. - Annu. Rev. Entomol. 39: 101-128.

Stearns S.C. 1992: The Evolution of Life Histories. Oxford University Press, Oxford, $264 \mathrm{pp}$.

StorozHenKo S.Yu. 2009: An annotated list of grasshoppers and their allies (Orthoptera: Caelifera) of the Asian part of Russia. - Korean J. Soil Zool. 13: 10-24.

Tomkins J.L. \& HAZEL W. 2007: The status of the conditional evolutionarily stable strategy. - Trends Ecol. Evol. 22: $522-528$.

WeST-EBerhard M.J. 2003: Developmental plasticity and evolution. Oxford University Press, New York, 794 pp.

Whiteman H.H., Wissinger S.A., Denoël M., Mecklin C.J., GERLANC N.M. \& Gutrich J.J. 2012: Larval growth in polyphenic salamanders: making the best of a bad lot. - Oecologia 168: 109-118.

Whitman D.W. 2008: The significance of body size in the Orthoptera: a review - J. Orthopt. Res. 17: 117-134.

Yamashita H., Kiritani K., Togashi K. \& Kubota K. 2006: Wing dimorphism in three carabid species living in the grasslands of Mt. Omuro, Shizuoka, Japan. - Appl. Entomol. Zool. 41: 463-470.

ZERA A.J. 2005: Intermediary metabolism and life history tradeoffs: lipid metabolism in lines of the wing-polymorphic cricket, Gryllus firmus, selected for flight capability vs. early age reproduction. - Integr. Comp. Biol. 45: 511-524.

ZeRA A.J. 2009: Wing polymorphism in Gryllus (Orthoptera: Gryllidae): proximate endocrine, energetic and biochemical mechanisms underlying morph specialization for flight vs. reproduction. In Whitman D.W. \& Ananthakrishnan T.N. (eds): Phenotypic Plasticity of Insects. Mechanism and Consequences. Science Publishers, Enfield, pp. 609-653.

Zera A.J. \& Denno R.F. 1997: Physiology and ecology of dispersal polymorphism in insects. - Annu. Rev. Entomol. 42: 207-231.

ZeRA A.J. \& ZhaO Z. 2006: Intermediary metabolism and lifehistory trade-offs: differential metabolism of amino acids underlies the dispersal-reproduction trade-off in a wingpolymorphic cricket. - Am. Nat. 167: 889-900.

Received February 8, 2013; revised and accepted March 14, 2013 